\title{
Effective Thermal Conductivities in the Central Parts of Plant Stems
}

\author{
Uzuki Matsushima and Kazunori IwABUCHI \\ Faculty of Agriculture, Yamagata University, Tsuruoka 997, Japan
}

(Received March 27, 1996)

\begin{abstract}
The effective thermal conductivities for longitudinal and transverse heat flow in the central parts of corn and sunflower stems were measured using the line heat source method. Most of the effective thermal conductivities of the plant stems were found to be less than $0.2 \mathrm{~W} \mathrm{~m}^{-1} \mathrm{~K}^{-1}$, with the exception of samples having a high water ratio. These low values are probably attributed to the high gas ratio in the central parts of the plant stem. The difference between the longitudinal and transverse thermal conductivities of the plant stems was not found to be significant.
\end{abstract}

\section{INTRODUCTION}

Since plant growth is greatly influenced by plant temperature, it is useful to determine the effective thermal conductivities of plants so that plant temperatures can be predicted and controlled. MacLean et al. (1941) measured the effective thermal conductivities of various kinds of woods, and showed that effective thermal conductivity increased linearly with water content. Turrell and Austin (1967) measured the effective thermal conductivities of four varieties of citrus wood, and found results similar to those obtained by MacLean. MacLean and Turrell both used the steady state method to determine the effective thermal conductivity. However, this method can be difficult to use with moist materials such as plants, and can lead to erroneous measurements because of the internal liquid and air convection caused by forced heating during measurement. A transient method is thus more appropriate for determining the thermal properties of moist materials.

The present investigation determined the effective thermal conductivities in the central parts of plant stems without sap flow. The effective thermal conductivity was determined using the line heat source method, which is a transient method. The investigation then determined the relationship between the effective thermal conductivities of the plant stems and their water ratio, and the effective thermal conductivities for longitudinal and transverse heat flow.

\section{PRINCIPLES}

Assuming an infinitely long line heater in an infinite, homogeneous and isotropic medium, the radial heat flow away from the heat source can be described by a one dimensional heat equation based on cylindrical coordinates. The temperature rise $\theta$ at a radial distance $r$ from the line heat source is represented by the following equation developed by Van der Held and Van Drunen (1949): 


$$
\theta=-\left(\frac{Q}{4 \pi \lambda}\right) \cdot E_{1}\left(-\frac{r^{2}}{4 \alpha t}\right)
$$

where $Q$ is the heat production from the line heat source, $\lambda$ is the thermal conductivity, $\alpha$ is the thermal diffusivity, $t$ is time and $E_{\mathrm{i}}(-x)$ is an exponential integral function. For large values of $t$, the Eq. (1) can be expressed as:

$$
\theta=\left(\frac{Q}{4 \pi \lambda}\right) \cdot\left\{\ln \left(\frac{4 \alpha e^{-\gamma}}{r^{2}}\right)+\ln t\right\}
$$

where $\gamma$ is Euler's constant.

The gradient of a plot of $\theta$ versus $\ln t(=k)$ is equal to $Q /(4 \pi \lambda)$. The thermal conductivity is thus calculated by using Eq. (3) :

$$
\lambda=\frac{Q}{4 \pi k} .
$$

\section{MATERIALS AND METHODS}

Two kinds of plants were used for measurements. One was the monocotyledon of a corn plant (Zea mays L. cv. Honey Bantam). The other was the dicotyledon of a sunflower plant (Hellanthus annuus L. cv. Kokuryu). Both plants were grown on a research farm at Yamagata University. The plant stems, which ranged in diameter from 1.5 to $3 \mathrm{~cm}$, were cut into $3 \mathrm{~cm}$ lengths. These pieces were then wrapped in vinyl sheets to protect them from dehydration, and were kept in a temperature controlled room for 12 hours to stabilize their temperature at $20^{\circ} \mathrm{C}$.

A combination heater and thermocouple was inserted through the central portion of the stem, either longitudinally or transversely (see Fig. 1). DC power was supplied to the heater wire for a period of one minute, during which time the temperature was recorded at $0.5 \mathrm{~s}$ intervals by a datalogger. The applied electric current was measured with a digital current meter.

The water ratio in a plant stem is the volume fraction of water to the total volume of the stem. The volume of water was calculated by measuring the weight of moisture removed when the stem was dried for $24 \mathrm{~h}$ at $105^{\circ} \mathrm{C}$ in an electric drying oven. The solid ratio in a plant stem is the volume fraction of solid to the total volume of the stem. The volume of solid was calculated using both the specific gravity and the dried solid weight. The gas ratio in a plant stem is the volume fraction of gas to the total volume of the stem.

To check the accuracy of the experimental methods, we measured the effective thermal

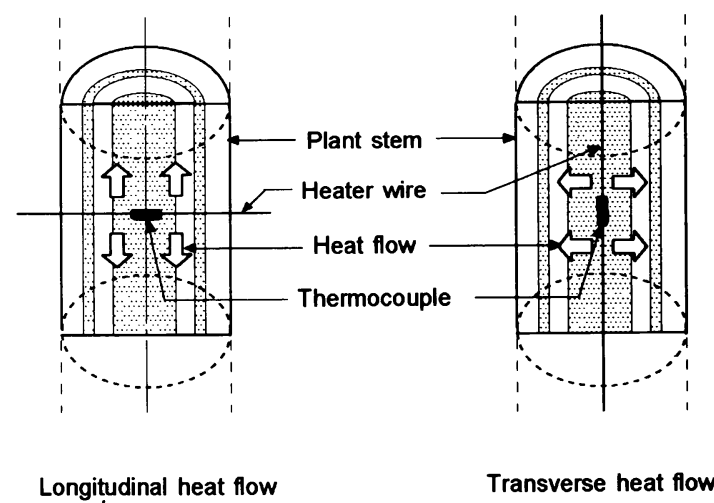

Fig. 1 Methodology for measuring the effective thermal conductivity of plant stems. 
conductivities of a standard material, agar gel $(2 \%, w / v)$. The effective thermal conductivity of agar gel is almost the same as that of water (Kasubuchi, 1977). Moreover, liquid convection due to heating hardly occurs in agar gel. We shaped the agar gel into a column $1.5 \mathrm{~cm}$ diameter and $3 \mathrm{~cm}$ length, so the gel shape would be similar to the sample of the plant stem. The effective thermal conductivities in the agar gel were found to be almost equal to the values reported in the literature for water at $20^{\circ} \mathrm{C}$ (Holman, 1986). Thus, it was concluded that the method is suitable for measuring the effective thermal conductivities of small and moist materials.

\section{RESULTS AND DISCUSSION}

Fig. 2 shows the relationship between effective thermal conductivity in the central parts of the plant stems and water ratio. The open and closed circles represent the effective thermal conductivities for transverse and longitudinal heat flow respectively. The effective thermal conductivity tended to increase with the water ratio, and to be less than about $0.4 \mathrm{~W} \mathrm{~m}^{-1} \mathrm{~K}^{-1}$. In most cases, the effective thermal conductivity was less than $0.2 \mathrm{~W} \mathrm{~m}^{-1} \mathrm{~K}^{-1}$, which is quite low. These low values can be attributed to the high gas ratio which is $45 \%$ in mean value, in the central parts of the plant stem. Because the high gas ratio would make more discontinuous and tortuous pathways for heat conduction in the water filmed on the solids. For materials with a higher water content, Sakuratani (1984) calculated the effective thermal conductivities of crop plant stems, and described them as ranging from 0.52 to $0.58 \mathrm{~W} \mathrm{~m}^{-1} \mathrm{~K}^{-1}$. Our results are consistent with Sakuratani's findings, with higher thermal conductivities occurring in corn stems that have a higher water ratio. Thus, the effective thermal conductiv-
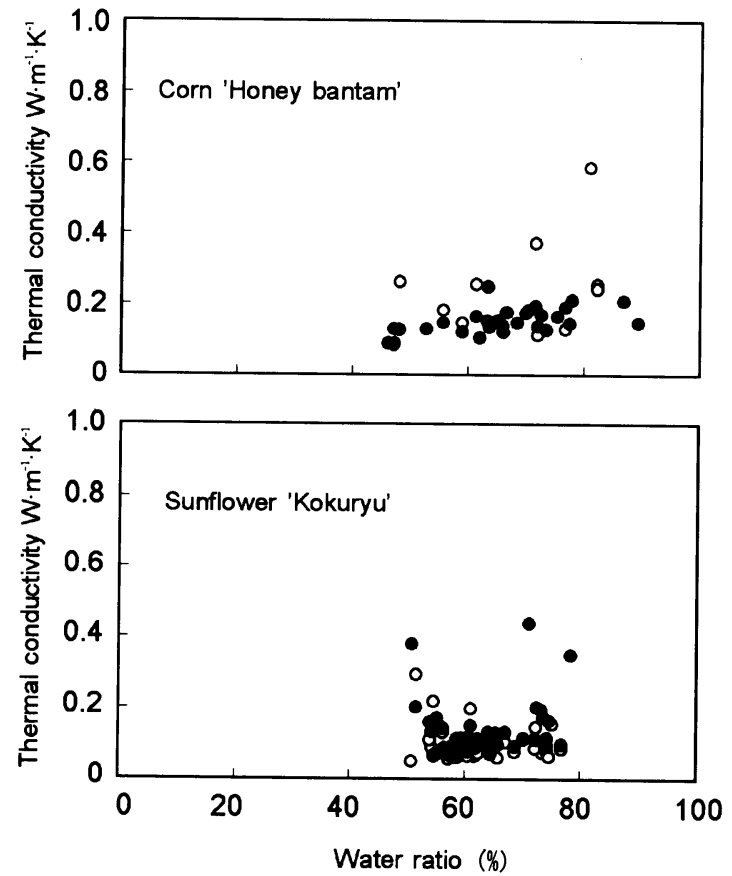

Fig. 2 Relationship between the effective thermal conductivities in the central portion of the plant stems and the water ratio.

Closed circle, thermal conductivity for longitudinal heat flow ; open circle, thermal conductivity for transverse heat flow. 
ities in the central parts of plant stems would be low (less than $0.2 \mathrm{~W} \mathrm{~m}^{-1} \mathrm{~K}^{-1}$ ), except when the water ratio is high.

Turrell and Austin (1967) reported that the effective thermal conductivities of citrus wood differed significantly between longitudinal and transverse heat flow. Turrell suggested that this was a result of the fact that wood consists of tissues with a specific orientation. But, as shown in Fig. 2, we did not observe a significant difference between the longitudinal and transverse thermal conductivities. This may be due to the fact that the central parts of corn and sunflower stems consist of isotropic tissues.

\section{NOMENCLATURE}

$Q$, heat production $\left(\mathrm{W} \mathrm{m}^{-1}\right) ; r$, radial distance from line heat source $(\mathrm{m}) ; t$, time $(\mathrm{s}) ; \alpha$, thermal diffusivity $\left(\mathrm{m}^{2} \mathrm{~s}^{-1}\right) ; \gamma$, Euler's constant $(0.5772) ; \lambda$, effective thermal conductivity $\left(\mathrm{W} \mathrm{m}^{-1} \mathrm{~K}^{-1}\right) ; \theta$, temperature $\left({ }^{\circ} \mathrm{C}\right)$.

\section{REFERENCES}

Holman, J. P. 1986. Heat Transfer, Ed. 6., McGraw-Hill Book Co., New York, p 635-647.

Kasubuchi, T. 1977. Twin transient-state cylindrical-probe method for the determination of the thermal conductivity of Soil. Soil Sci. $124: 255-258$.

MacLean, J. D. 1941. Thermal conductivity of wood. ASHVE Trans. $47: 323-354$.

Sakuratani, T. 1984. Improvement of the probe for measuring water flow rate in intact plants with the stem heat balance method. J. Agric. Met. $40: 273-277$.

Turrell, F. M., Austin, S. W. 1967. Thermal conductivity of functional citrus tree wood. Plant Physiol. 42: $1025-1034$.

Van der Held, E. F. M., Van Drunen, F. G. 1949. A method of measuring the thermal conductivity of liquids. Physica $15: 865-881$.

\section{〈和文抄録〉}

\section{植物の主荎中心部における有効熱伝導率 \\ 松嶋卯月・岩㹸和則 \\ 山形大学農学部}

線熱源法によってトウモロコシとヒマワリ主茎中心部における鉛直および水平方向熱流に対す る有効熱伝導率を計測した. 有効熱伝導率の值の多くは, 高液相率の時を除き, $0.2 \mathrm{~W} \mathrm{~m}^{-1} \mathrm{~K}^{-1}$ 以 下と低いものであった。これは主茎中心部の気相率が平均 $45 \%$ と非常に高いことが原因と考えら れた. 主茎中心部における鉛直および水平方向熱流に対する有効熱伝導率については, 顕著な差は 観測されなかった。 